\title{
Sedative and Anxiolytic Effects of Methanolic Extract from the Leaves of Passiflora actinia
}

\author{
Kely Cristina dos Santos ${ }^{1}$, Stella Maris Tessaro Figura Kurtz ${ }^{1}$, Simony Davet Müller ${ }^{2}$, \\ Maique Weber Biavatti ${ }^{2}$, Rúbia Maria Monteiro Weffort de Oliveira ${ }^{3}$ and Cid Aimbiré de \\ Moraes Santos ${ }^{1 *}$ \\ ${ }^{1}$ Laboratório de Farmacognosia; Departamento de Farmácia; Universidade Federal do Paraná; Rua Prefeito \\ Lothario Meissner, 3400; Jd. Botânico; cid@ufpr.br; 80210-170 - Curitiba - PR -Brasil. ${ }^{2}$ Núcleo de Investigações \\ Químico-Farmacêutica; Universidade do Vale do Itajaí; C. P. 360; 88302-20; Itajaí - SC -Brasil. ${ }^{3}$ Departamento de \\ Farmácia e Farmacologia; Universidade Estadual de Maringá; Av. Colombo, 5790; Jardim Universitário; Bloco \\ K-80; 87020-900; Maringá -PR - Brasil
}

\begin{abstract}
Leaves from several Passiflora species are largely employed in the Brazilian folk medicine as anxiolytic and sedative. In this work the anxiolytic, sedative-like properties and liquid chromatography analysis of methanolic extract of Passiflora actinia were evaluated. The methanol extract and all of its fractions presented significant sedative-like effect in elevated plus-maze and open field tests. Only the aqueous fraction of the methanol extract showed selective anxiolytic activity $(30 \mathrm{mg} / \mathrm{kg})$. Chromatographic analysis of the active fractions showed the presence of isovitexin and absence of the classical Passiflora $\beta$-carboline alkaloids or flavonoids such as vitexin, rutin, swertisin, hesperidin and orientin. The tincture obtained from P. actinia leaves presented $0.27 \mathrm{mg} / \mathrm{ml}$ of isovitexin and absence of vitexin.
\end{abstract}

Key words: Anxiolytic, sedative, isovitexin, Passiflora actinia, Passifloraceae

\section{INTRODUCTION}

In folk medicine, some wildspread Passiflora's species have been used for their sedative and anxiolytic effects. The principal bioactive compounds described in this genus are $C$-glycosil flavonoids (vitexin, isovitexin, orientin, isoorientin and apigenin) and $\beta$-carbolinic alkaloids (harman, harmin, harmalin, harmol and harmalol) (Blumenthal et al., 2000). Some reports have pointed out the harman alkaloids (Alonso, 1998) as the bioactive constituents of Passiflora incarnata Linneu, one of the species of Passiflora that have been extensively studied chemically and biologically (Dhawan et al., 2001; Soulimani et al., 1997). Others indicate the flavonoid chrysin (Wolfman et al., 1994; Zanoli et al., 2000) or even maltol (Aoyagi et al., 1974) as the putative substances responsible for the tranquilizer activities.

Passiflora actinia Hooker (vernacular name: maracujá-do-mato) is a liana widely distributed through Southern Brazil. Unlikely P. incarnata, so far there has been no report in literature about this species. It grows very well on the Brazilian soil (Cervi, 1981), which makes it a potential alternative for $P$. incarnata. The aim of the present study was to evaluate the possible anxiolytic and

\footnotetext{
* Author for correspondence
} 
sedative properties of $P$. actinia methanol extract and its fractions in mice. Chromatographic analyses were performed in order to investigate the presence of some compounds previously described in the genus with hypothetical activity on these two parameters at the central nervous system (CNS).

\section{MATERIALS AND METHODS}

\section{Plant material}

Leaves of $P$. actinia Hooker were collected in Canguiri's Farm, Pinhais, Paraná, Brazil (November 2001) and the plant was identified by Dr. Armando Cervi. A voucher specimen was deposited at the Department of Botany Herbarium (UPCB $\mathrm{n}^{\circ}$ 30.831), Universidade Federal do Paraná, PR, Brazil.

\section{Preparation of extracts and fractions}

The dried and powdered $P$. actinia leaves $(750 \mathrm{~g})$ were exhaustively and successively extracted in a Soxhlet apparatus with petroleum ether, $\mathrm{CHCl}_{3}$ and $\mathrm{MeOH}$. Subsequently, the $\mathrm{MeOH}$ extract (100 g) was suspended in distilled water $(1000 \mathrm{ml})$, shaken in water-iced bath for $8 \mathrm{~h}$ and refrigerated for $12 \mathrm{~h}$. An aliquot $(800 \mathrm{ml})$ of the filtered extract was alkalinized by $\mathrm{NaHCO}_{3}(\mathrm{pH}$ 9.5) and partitioned sequentially with $n$-hexane and $\mathrm{CHCl}_{3}$ to yield $6.78 \mathrm{~g}$ and $3.77 \mathrm{~g}$, respectively after drying the solvents under vacuum. The remaining $\mathrm{H}_{2} \mathrm{O}$ extract (aqueous fraction, $70.3 \mathrm{~g}$ ) was subjected to column chromatography (aluminum oxide 90 Merck, activity I-II seg. Brokmann) eluted with a gradient of $\mathrm{CHCl}_{3}-\mathrm{MeOH}-\mathrm{H}_{2} \mathrm{O}$. The resulting joined fractions 3-6 (A, $1.8 \mathrm{~g}), 7-13(\mathrm{~B}$, $2.7 \mathrm{~g})$ and 14-16 (C, $2.3 \mathrm{~g})$ were subjected to liquid chromatography (LC) analysis and to biological tests as well as the crude $\mathrm{MeOH}$ extract and its fractions. The dosage form (tincture) was prepared with $45 \%$ ethanol in water, according to the Brazilian Pharmacopoeia $2^{\text {nd }}$ Edition and Newall et al (1996).

\section{Chromatographic analysis}

HPLC analyses were performed using a Shimadzu LC-10AD (Tokyo, Japan) pump, a Luna RPC18 (5 $\mu \mathrm{m}),(250 \times 4.6 \mathrm{~mm}$ i.d., $5 \mu \mathrm{m})$ column from Phenomenex (Torrance, CA, USA), a Shidmadzu SPD-M10A photodiode array detector and a Shimadzu CTO-10A column oven fit to $30^{\circ} \mathrm{C}$. A
Rheodyne manual injector model $7725 \mathrm{i}$ was used for sample injection (Rohnert Park, CA, USA). All reagents used were HPLC grade. The $C$-glycosil flavonoids and the harmane alkaloids analyses consisted of linear gradient system with a flowrate of 1 and $0.8 \mathrm{ml} / \mathrm{min}$ respectively, at $30^{\circ} \mathrm{C}$.

Gradient elution for flavonoids analysis was: $1-20$ min $10 \%$ solvent $\mathrm{B}(\mathrm{MeOH})$ and $(10 \%) \mathrm{C}(\mathrm{MeCN})$ in $\mathrm{A}\left(\mathrm{H}_{2} \mathrm{O}-\mathrm{HOAc}, 100: 0.5, \mathrm{pH} 2.88\right), 20-30 \mathrm{~min}$ $15 \% \mathrm{~B}$ and $\mathrm{C}$ in $\mathrm{A}, 30-35 \mathrm{~min} 20 \% \mathrm{~B}$ and $\mathrm{C}$ in $\mathrm{A}$. The $C$-flavonoids (orientin, swertisin, vitexin, isovitexin) and also rutin and hesperidin were monitored at $340 \mathrm{~nm}$. Gradient elution for alkaloids analysis was: $0-5 \min 12 \%$ solvent $\mathrm{B}$ $(\mathrm{MeOH})$ and $32 \%$ solvent $\mathrm{C}(\mathrm{MeCN})$ in $\mathrm{A}$ (phosphate buffer, $\mathrm{pH} 8.0$ ), 5-18 $\min 20 \% \mathrm{~B}$ and $40 \% \mathrm{C}$ in $\mathrm{A}, 18-30$ min $12 \% \mathrm{~B}$ and $32 \% \mathrm{C}$ in $\mathrm{A}$. The harmane alkaloids harman, harmin, harmalol, harmol and harmaline (Fluka) were monitored at $350 \mathrm{~nm}$. For the qualitative flavonoid analysis an isocratic elution mode $\left(\mathrm{MeCN}-\mathrm{H}_{2} \mathrm{O}-\mathrm{HOAc}\right.$ 18:82:0,5) with a $1 \mathrm{ml} / \mathrm{min}$ flow rate was also employed. Extracts and standards were diluted in $\mathrm{MeOH} / \mathrm{H}_{2} \mathrm{O} \quad(1: 1) \quad(1: 10$ and $2: 100 \quad \mathrm{v} / \mathrm{v}$ respectively), filtered over regenerated cellulose membrane of $0.45 \mu \mathrm{m}$ pore diameter (Schleicher and, Schuell, Dassel, Germany) and injected (20 $\mu 1)$. Isovitexin was determined in the plant material by external standard method (Snyder et al., 1997) at a concentration of $20 \mu \mathrm{g} / \mathrm{ml}$ diluted in triplicate to $4.0 ; 8.0 ; 12.0 ; 16.0$ and $20.0 \mu \mathrm{g} / \mathrm{ml}$. The software Shimadzu Class-VP 5.03 was used to fit the regression curve and for calculating the corresponding correlation coefficient. All samples were analysed in triplicate

\section{Animals \\ Male albino-Swiss mice (30-45 g), housed in groups $(n=5)$ with free access to food and water in a temperature controlled room $\left(23 \pm 1^{\circ} \mathrm{C}\right)$ with a 12 $\mathrm{h}$ light dark cycle, were used. The animals were allowed to acclimate to the testing room for at least $1 \mathrm{~h}$ prior the behavioral testing, which occurred between 9 to $12 \mathrm{am}$. The experiments were carried out according to the National Institute of Health Guide for Care and Use of Laboratory Animals, and all efforts were made to minimize animal suffering.}

\section{Treatments}

Methanol extract $(100,300$ and $600 \mathrm{mg} / \mathrm{kg})$, as well as $n$-hexane, $\mathrm{CHCl}_{3}$ and aqueous crude 
fractions (30, 100 and $300 \mathrm{mg} / \mathrm{kg})$, and chromatographic fractions A to $\mathrm{C}(10,30$ and 100 $\mathrm{mg} / \mathrm{kg}$ ) of $P$. actinia were administered intraperitoneally (i.p.) $30 \mathrm{~min}$ before the behavioural tests at a volume of $10 \mathrm{ml} / \mathrm{kg}$. The extracts and fractions were solubilized in saline ( $\mathrm{NaCl}, 0.9 \%)$ while $n$-hexane and $\mathrm{CHCl}_{3}$ crude fractions were solubilized in saline containing $2 \%$ DMSO. Diazepam (Dienpax, Sanofi-Wintrop Lab., Brazil, $1.0 \mathrm{mg} / \mathrm{kg}$ ), used as a reference drug (positive control), was dissolved in FBB (propyleneglycol 60\%, benzyl alcohol 2\% in water) immediately before i.p. administration.

\section{Behavioural tests}

Elevated plus maze: The method initially suggested by Handley and Mithani (1984) was employed with minor modifications (Lister, 1987). The mice were individually placed in the center of the elevated plus maze and were allowed $5 \mathrm{~min}$ for free exploration. All sessions were videotaped. Afterwards, the number of open and enclosed arm entries, and time spent on open arms were manually registered. The percentage of open arm entries $(100 \mathrm{x}$ open/total entries $)$ and the percentage of time spent in the open arms $(100 \mathrm{x}$ open/open + enclosed) were calculated for each animal.

Open field: Immediately after the elevated plus maze test, the animals were placed into the center of the open field in order to measure the locomotor activity (Royce, 1977). The animals could explore the space during $5 \mathrm{~min}$. Sessions were videotaped and subsequently, hand operated counters and stopwatches were used to score the number of crossings (number of square floor units entered) and rearing (number of times the animal stood on hind legs).

Statistical analysis: The data were analyzed by $t$ Student test or one-way analysis of variance (ANOVA) followed by the Tukey's test for multiple comparisons.

\section{RESULTS}

\section{Chromatographic analysis}

The chromatographic analysis of the active crude methanol extract and of the generated fractions showed absence of the classical $\beta$-carboline tested alkaloids (harman, harmin, harmalol, harmol and harmaline). The methanol extract and the aqueous fraction presented similar profile when analyzed under the flavonoid conditions. Only isovitexin was found in quantifiable amounts while traces of vitexin were detected in the fractions $\mathrm{B}$ and $\mathrm{C}$. The flavonoids swertisin, rutin, orientin and hesperidin were not found in all fractions and extract tested. The methanolic extract, aqueous crude fraction, fractions $\mathrm{B}$ and $\mathrm{C}$ clearly presented other unidentified flavonoids than isovitexin according to their UV profile in the PDA detector. Quantitative HPLC analysis of $P$. actinia tincture showed $0.27 \mathrm{mg} / \mathrm{ml}$ of isovitexin, absence of vitexin and the presence of some other unidentified flavonoids. $\mathrm{CHCl}_{3}$ and $n$-hexane fractions, as well as fraction A did not show a flavonoid profile in the PDA detector.

\section{Behavioral tests}

As seen in Fig. 1, the reference drug, diazepam (1 $\mathrm{mg} / \mathrm{kg})$, increased the percentage of entries $(\mathrm{t}=3.7$, $\mathrm{df}=16, \mathrm{p}=0.0022)$ and of the time $(\mathrm{t}=3.6, \mathrm{df}=16$, $\mathrm{p}=0.0026$ ) spent in the open arms of the elevated plus maze, without changing the number of enclosed arm entries.

Acute treatment with crude methanol extract of $P$. actinia at 300 and $600 \mathrm{mg} / \mathrm{kg}$, significantly decreased the percentage of entries $\left(\mathrm{F}_{3,40}=7.0\right.$, $\mathrm{p}<0.05)$ and the percentage of time spend in the open arms $\left(F_{3,40}=9.8, p<0.05\right.$, Fig. 2$)$ of the elevated plus maze. In addition, the same doses significantly decreased the number of enclosed arm entries $\left(\mathrm{F}_{3,40}=5.2, \mathrm{p}<0.05\right)$.

The administration of the aqueous crude fraction of $P$. actinia $30 \mathrm{mg} / \mathrm{kg}$ (Fig. 3) produced a significant increase in the percentage of entries $\left(\mathrm{F}_{3,46}=6.7, \mathrm{p}<0.05\right)$ and in the percentage of time spent in the open arms of the elevated plus maze $\left(\mathrm{F}_{3,46}=10.46, \mathrm{p}<0.05\right)$ without any change in the number of enclosed entries. Higher doses of this fraction (100 and $300 \mathrm{mg} / \mathrm{kg})$, significantly decreased the number enclosed arm entries $\left(\mathrm{F}_{3,46}=\right.$ 20.5, $\mathrm{p}<0.001$ ). The $n$-hexane and $\mathrm{CHCl}_{3}$ fractions failed to modify the parameters analyzed in the elevated plus maze test (data not shown). Fraction $\mathrm{C}$ showed a significant effect on the enclosed entries at doses of 30 and $100 \mathrm{mg} / \mathrm{kg}\left(\mathrm{F}_{3.39}=7.1\right.$, $\mathrm{p}<0.05$ ).

As shown in Fig. 4, fraction $\mathrm{A}(10,30$ and 100 $\left.\mathrm{mg} / \mathrm{kg} ; \mathrm{F}_{3.41}=30.5\right)$ and fraction $\mathrm{B}(10,30$ and 100 $\left.\mathrm{mg} / \mathrm{kg}, \mathrm{F}_{3.41}=12.1\right)$ also significantly $(\mathrm{p}<0.05)$ decreased the number of enclosed entries. 
However, only the fraction $\mathrm{C}$ produced a significant decrease in the percentage of open arm entries $\left(\mathrm{F}_{3.41}=5.24, \mathrm{p}<0.05\right)$ in the elevated plus maze. All together these results show a general decrease in the animal locomotion's activity.

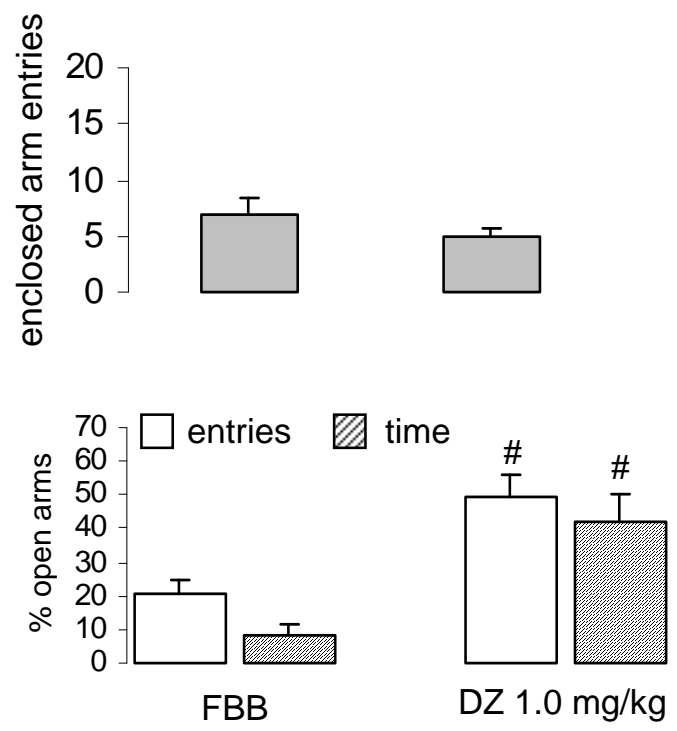

Figure 1 - Anxiolytic effect of diazepam (DZ, $1 \mathrm{mg} / \mathrm{kg}$ ) i.p. administered in mice, $30 \mathrm{~min}$ before the elevated plus-maze testing $(5 \mathrm{~min})$. Observe the selective enhance in the number of entries and time spent into the open arms (anxiolytic effect) without changing the enclosed arm entries. Columns represent the means and the bars refer to the SEM (standard error of the means) of the groups $(n=9-12) . ~ " ~ p<0.05$ compared to saline by the $t$ Student test.

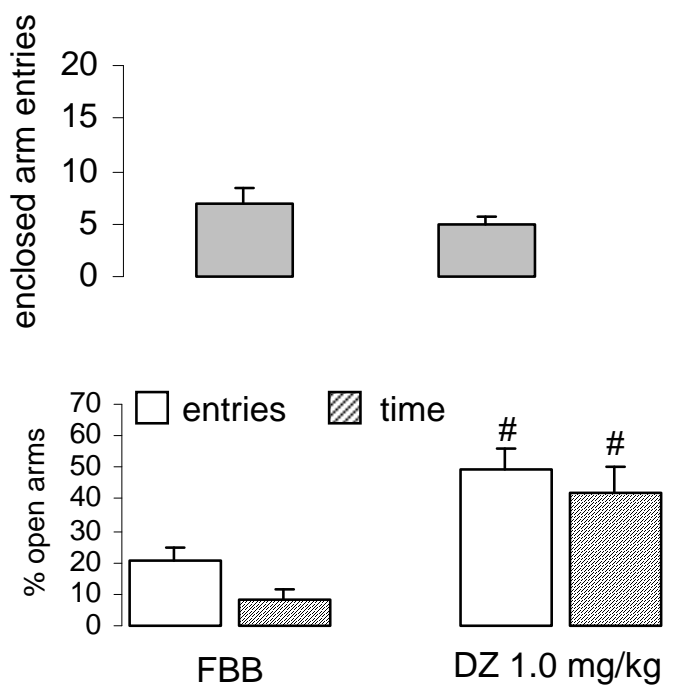

Figure 2 - Sedative effect of methanol extract of Passiflora actinia (100, 300 and $600 \mathrm{mg} / \mathrm{kg})$ i.p. administered in mice, $30 \mathrm{~min}$ before the elevated plus-maze testing $(5 \mathrm{~min})$. Columns represent the means and the bars refer to the SEM of the groups $(n=10-12)$ *p $<0.05$ compared to saline by ANOVA followed by the Tukey's test. Further details as in Figure 1 

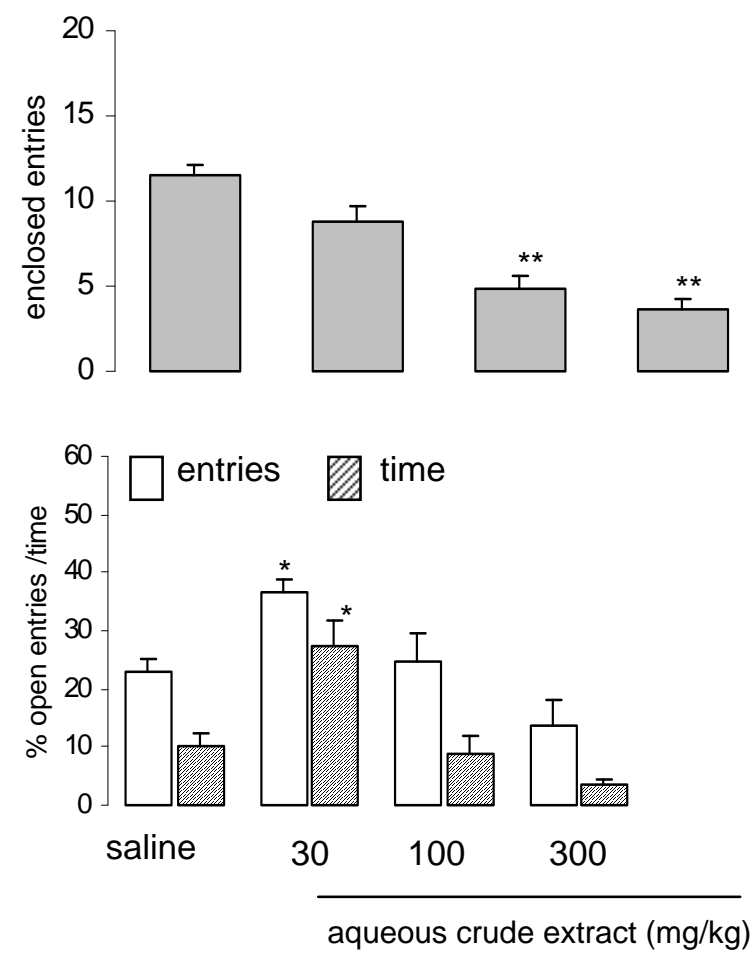

Figure 3 - Effects of the aqueous crude fraction of Passiflora actinia (30mg/kg, i.p.) in mice. Observe a sedative effect of the extract evidenced by a decrease in the number of the enclosed arm entries. The anxiolytic effect is characterized by a significant enhance in the $\%$ of entries and time into the open arms of the maze. Columns represent the means and the bars refer to the SEM of the groups $(n=10-12)$. $* \mathrm{p}<0.05$ and $* * \mathrm{p}<0.001$ compared to saline by ANOVA followed by the Tukey's test. Further details as in Figure 1.

The effects of $P$. actinia methanol extract and fractions on the open field test are shown in Table 1. The administration of methanol extract of $P$. actinia produced a significant decrease in the number of rearing (300 and $600 \mathrm{mg} / \mathrm{kg}, \mathrm{F}_{3,40}=6.2$, $\mathrm{p}<0.05)$ and crossings $\left(600 \mathrm{mg} / \mathrm{kg}, \mathrm{F}_{3.40}=4.5\right.$, $\mathrm{p}<0.05)$. Both doses of 100 and $300 \mathrm{mg} / \mathrm{kg}$ aqueous crude fraction of $P$. actinia decreased the number of rearing $\left(\mathrm{F}_{3,46}=21.4, \mathrm{p}<0.05\right)$ while only dose of $300 \mathrm{mg} / \mathrm{kg}$ significantly altered the number of crossings $\left(\mathrm{F}_{3,46}=15.14, \mathrm{p}<0.001\right)$. A significant decreased effect on locomotor activity of the animals was observed with fractions $\mathrm{A}$ and $\mathrm{B}$ at dose of $100 \mathrm{mg} / \mathrm{kg}$ either for the number of rearing $\left(\mathrm{A}, \mathrm{F}_{3,41}=34.20, \mathrm{p}<0.001 ; \mathrm{B}, \mathrm{F}_{3,41}=6.2, \mathrm{p}<0.001\right)$ or number of crossings $\left(A, F_{3,41}=15.65, p<0.001\right.$; $\left.\mathrm{B}, \mathrm{F}_{3,41}=3.6, \mathrm{p}<0.05\right)$ (Table 1). Fraction $\mathrm{C}(30$ and $100 \mathrm{mg} / \mathrm{kg}$ ) also produced a significant decrease in the number of rearing $\left(\mathrm{F}_{3,39}=7.7\right.$, $\mathrm{p}<0.05)$ and crossings $\left(100 \mathrm{mg} / \mathrm{kg}, \mathrm{F}_{3,39}=2.9\right.$, $\mathrm{p}<0.05)$. 

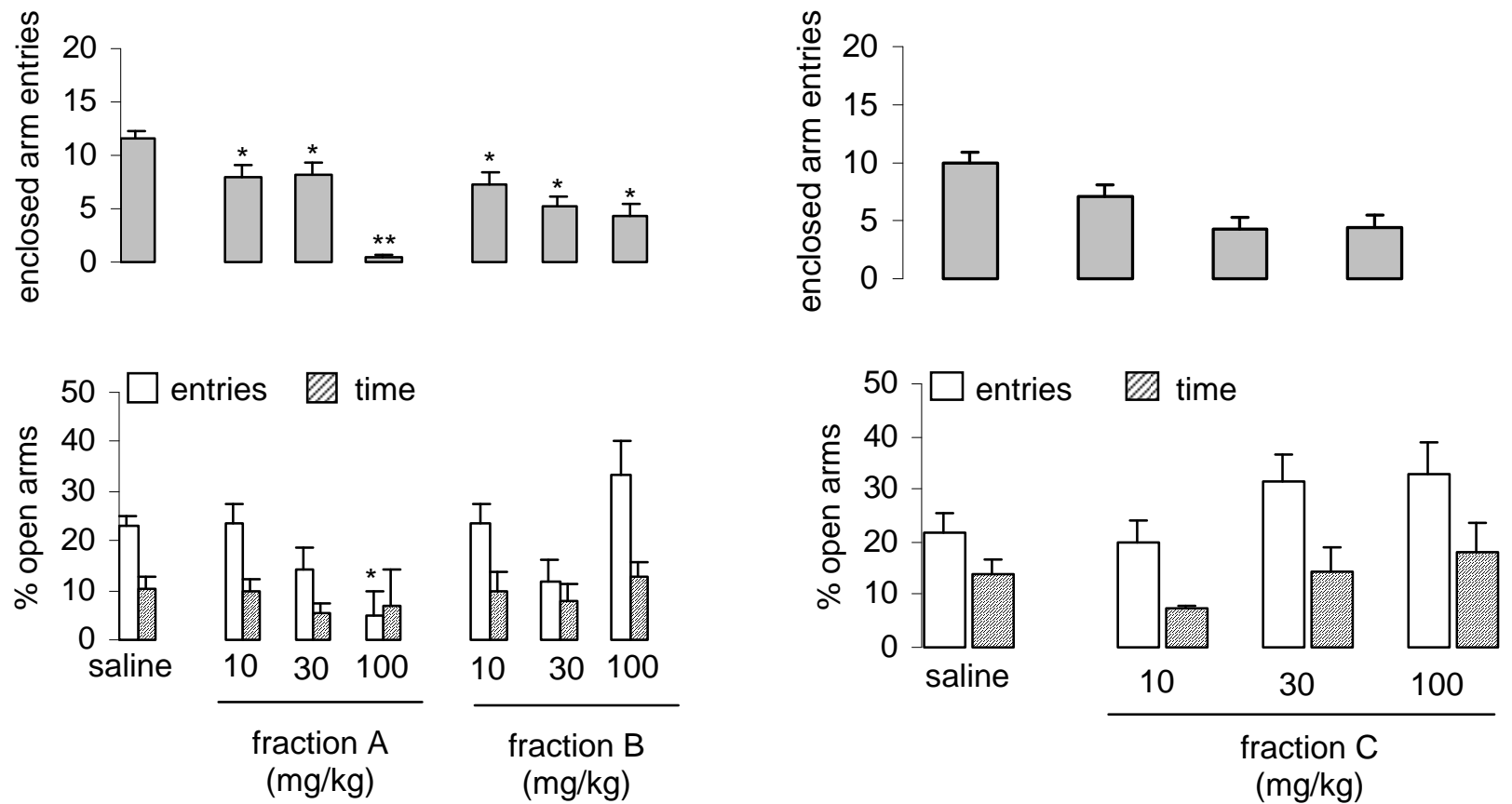

Figure 4 - Sedative effects of i.p. administration of the fractions A and B (panel I) and fraction C (panel II) of P. actinia $(10,30$ and $100 \mathrm{mg} / \mathrm{kg}$ ) in mice submitted to the elevated plus-maze for 5 minutes. Columns represent the means and bars the SEM of 10-12 animals. $* \mathrm{p}<0.05$ compared to saline or saline containing $2 \%$ DMSO (sal/DMSO) by ANOVA followed by the Tukey's test. Further details as in Figure 1.

\section{DISCUSION}

The elevated plus maze test has been recognized as a valuable model able to predict anxiolytic or anxiogenic effects of drugs in rodents (Lister, 1987; Pellow and File, 1986). While anxiolytic compounds typically increase the percentage of open arms entries as well as the time spend in open arms, anxiogenics have the opposite effects. In addition, the number of the enclosed entries has been used as a parameter reflecting general motor activity. Confirming previous results (Bhattacharya, Mitra, 1991), the i.p. administration of diazepam $(1 \mathrm{mg} / \mathrm{kg})$ resulted in anxiolytic-like effect, characterized by an increase in the percentage of exploration in the open arms of the plus maze (Fig. 1). The methanol extract (300 and $600 \mathrm{mg} / \mathrm{kg}$ ), otherwise, decreased the entries and time spent in the open arms (Fig. 2). Although this is usually interpreted as an anxiogenic effect, the extract administration also decreased the number of enclosed arms entries as well as the number of crossings and rearings in the open field test
(Table 1), suggesting a sedative-like effect more than an anxiogenic effect. Furthermore, a decreased general activity was also observed after the administration of $\mathrm{A}, \mathrm{B}$ and $\mathrm{C}$ fractions in lower doses as compared to the methanol extract, suggesting a major concentration of the putative active principle.

Interestingly, only the aqueous fraction at 30 $\mathrm{mg} / \mathrm{kg}$ presented a selective anxiolytic effect evidenced by an increase of the percentage of open entries and time spent in the open arms without changing the number of enclosed entries (Fig. 3). Different results were described by Soulimani et al. (1997) using $P$. incarnata extracts. The authors observed that the aqueous extracts (400 and 800 $\mathrm{mg} / \mathrm{kg}$ ) induced sedative effects while the hydroalcoholic extract $(400 \mathrm{mg} / \mathrm{kg})$ produced anxiolytic effect. Furthermore, the observed different effects were attributed to the solvents used to prepare the extracts. In the present work, the aqueous extract of $P$. actinia produced anxiolytic and sedative effect depending on the doses administered (Fig. 3). 
Table 1 - Sedative effects of i.p. administration of Passiflora actinia methanol extract and its fractions on crossing and rearing behaviors in the open field. Mice $(n=10-12)$ were submitted to the open field apparatus for 5 min immediately after the elevated plus maze test. The numbers represent the mean \pm SEM of $10-12$ animals. " $\mathrm{p}<0.05$ by the $t$ Student Test; $* \mathrm{p}<0.05$ and $* * \mathrm{p}<0.001$ compared to vehicles (saline, FBB or sal/DMSO) by ANOVA followed by the Tukey's test. FBB = propyleneglycol $60 \%$, benzyl alcohol $2 \%$ in water); sal/DMSO= saline containing $2 \%$ DMSO.

\begin{tabular}{|c|c|c|}
\hline Treatment & Crossing & Rearing \\
\hline \multicolumn{3}{|l|}{ FBB } \\
\hline$(10 \mathrm{ml} / \mathrm{kg})$ & $49.0 \pm 2.8$ & $30.5 \pm 2.1$ \\
\hline $\begin{array}{c}\text { Diazepam } \\
(1.0 \mathrm{mg} / \mathrm{kg}) \\
\text { Saline }\end{array}$ & $40.7 \pm 4.0$ & $21.5 \pm 3.7^{\#}$ \\
\hline$(10 \mathrm{ml} / \mathrm{kg})$ & $74.7 \pm 6.2$ & $12.4 \pm 1.9$ \\
\hline \multicolumn{3}{|c|}{ Methanol extract } \\
\hline $100 \mathrm{mg} / \mathrm{kg}$ & $62.7 \pm 5.0$ & $14.6 \pm 2.9$ \\
\hline $300 \mathrm{mg} / \mathrm{kg}$ & $53.8 \pm 7.4$ & $4.0 \pm 1.2 *$ \\
\hline 600 mg/kg & $39.1 \pm 4.9^{*}$ & $1.9 \pm 0.4^{*}$ \\
\hline \multicolumn{2}{|l|}{ Saline } & $38.3 \pm 2.9$ \\
\hline \multicolumn{3}{|c|}{ Aqueous fraction } \\
\hline $30 \mathrm{mg} / \mathrm{kg}$ & $79.5 \pm 5.8$ & $46.4 \pm 3.5$ \\
\hline $100 \mathrm{mg} / \mathrm{kg}$ & $51.3 \pm 7.7$ & $21.1 \pm 4.0^{*}$ \\
\hline $300 \mathrm{mg} / \mathrm{kg}$ & $23.9 \pm 6.3^{* *}$ & $10.8 \pm 3.0^{*}$ \\
\hline \multicolumn{3}{|l|}{ Fraction A } \\
\hline $30 \mathrm{mg} / \mathrm{kg}$ & $66.2 \pm 9.8$ & $38.9 \pm 7.4$ \\
\hline $100 \mathrm{mg} / \mathrm{kg}$ & $57.3 \pm 3.8$ & $35.9 \pm 5.5$ \\
\hline $300 \mathrm{mg} / \mathrm{kg}$ & $0.7 \pm 0.5^{* *}$ & $0 \pm 0 * *$ \\
\hline \multicolumn{3}{|l|}{ Fraction B } \\
\hline $30 \mathrm{mg} / \mathrm{kg}$ & $57.3 \pm 7.5$ & $28.0 \pm 6.4$ \\
\hline $100 \mathrm{mg} / \mathrm{kg}$ & $56.0 \pm 6.1$ & $29.7 \pm 5.3$ \\
\hline $300 \mathrm{mg} / \mathrm{kg}$ & $41.6 \pm 5.2 *$ & $11.20 \pm 3.4 * *$ \\
\hline \multicolumn{3}{|l|}{ Sal/DMSO } \\
\hline \multicolumn{3}{|l|}{ Fraction C } \\
\hline $10 \mathrm{mg} / \mathrm{kg}$ & $42.2 \pm 6.3$ & $25.0 \pm 4.0$ \\
\hline $30 \mathrm{mg} / \mathrm{kg}$ & $48.0 \pm 4.9$ & $18.9 \pm 3.2 *$ \\
\hline $100 \mathrm{mg} / \mathrm{kg}$ & $38.4 \pm 6.3^{*}$ & $8.4 \pm 3.0^{* *}$ \\
\hline
\end{tabular}

In fact, sedative activity has been related to strong doses, while anxiolytic activity has been related to weak doses of plant extracts or reference drugs such as clorazepate (Rolland et al., 1991).

Although several reports have shown psychotropic effects for different species of Passiflora, there is no consensus about which substances are responsible for these effects. Increasing number of evidence point out the flavonoids as the responsible for the pharmacological effects. Vitexin, isovitexin, orientin, isoorientin (De-Paris et al., 2002) or chrysin (Wolfman et al., 1994; Zanoli, et al., 2000; Medina et al., 1990), have been involved in promoting the CNS effects. Recently, De Paris et al. (2002) have shown a correlation between the content of flavonoids found in aqueous extracts from Passiflora species and their psychotropic actions. In addition, Rocha et al. (2002) have suggested that orientin and isoorientin could be responsible for the observed anxiolytic-like effect of a butanolic fraction from Cecropia glazioui. However, controversial works report that pure vitexin and isovitexin showed no activity in CNS tests (Speroni and Minghetti, 1988) while orientin presented very mild anxiolytic effects (Okuyiama et al., 1996).

In this work isovitexin was present in most of the active extracts (methanol, aqueous, $\mathrm{B}$ and $\mathrm{C}$ fractions). Interestingly, in the fraction $\mathrm{A}$, one of those that showed the highest sedative activity at $100 \mathrm{mg} / \mathrm{kg}$ (Fig. 2), none of the classical bioactive flavonoids analysed were identified by LC. Also, 
the UV profile in the PDA detector did not indicate the presence of other unknown flavonoid, due to the absence of characteristic absorption spectra of this class of compounds. The classical alkaloid standards (harman, harmin, harmaline, harmol and harmalol) could not be detected in the methanol extract or fractions.

The results showed that methanol extract and fractions obtained from $P$. actinia leaves demonstrated sedative and anxiolytic activities. Possibly, the anxiolytic and sedative activities observed in this work were not only dependent on the flavonoid or alkaloid content and other compounds belonging to different phytochemical classes were involved in the biological response observed in this work. Further studies would be necessary to evaluate the contribution of other substances for the activity showed as it still remains to be determined which components were responsible for these effects.

\section{ACKNOWLEDGEMENTS}

The authors thank Prof. Dr. A. Cervi (Universidade Federal do Paraná) for identification the plant material.

\section{RESUMO}

Folhas de diversas espécies de Passiflora são amplamente empregadas na medicina popular brasileira como ansiolítica e sedativa. Neste trabalho, as propriedades ansiolíticas e sedativas e análise por cromatografia líquida dos extratos metanólicos de Passiflora actinia foram avaliados. $\mathrm{O}$ extrato metanólico e todas as suas frações apresentaram efeitos sedativos significativos nos testes de labirinto em cruz elevada e campo aberto. Somente a fração aquosa do extrato metanólico mostrou seletiva atividade sedativa $(30 \mathrm{mg} / \mathrm{kg})$. Análise cromatográfica das frações ativas mostraram a presença de isovitexina e ausência dos alcalóides $\beta$-carbolínicos clássicos de Passiflora ou flavonóides como vitexina, rutina, swertisina, hesperidina e orientina. A tintura obtida de $P$. actinia (folhas) apresentou 0,27 $\mathrm{mg} / \mathrm{ml}$ de isovitexina e ausência de vitexina.

\section{REFERENCES}

Alonso, J. R. (1998), Tratado de fitomedicina: bases clínicas y farmacológicas. Buenos Aires: ISIS. pp.786-792.

Aoyagi, N.; Kimura R. and Murata T. (1974), Studies on Passiflora incarnata dry extract. I. Isolation of maltol and pharmacological action of maltol and ethyl maltol. Chem. Pharm. Bull., 22, 1008-1013.

Bhattacharya, S. K. and Mitra, S. K.(1991), Anxiolytic activity of Panax ginseng roots: an experimental study. J. Ethnopharmacol., 34, 87-92.

Blumenthal, M.; Goldberg, A. and Brinckmann, J. (2000), Herbal Medicine: Expanded Comission E Monographs. Integrative Medicine, Newton Communications. pp.293-296.

Cervi, A. C. (1981), Revisão do gênero Passiflora L. (Passifloraceae) do Estado do Paraná, Brasil. PhD. Thesis, Faculdad de Biologia, Universidad de Barcelona. Barcelona.

De-Paris, F.; Petry, R. D.; Reginatto, F. H.; Gosmann, G.; Quevedo, J.; Salgueiro, J. B.; Kapczinski, F;; González-Ortega, G. and Schenkel, E. P. (2002), Pharmacochemical Study of Aqueous Extracts of Passiflora alata Dryander and Passiflora edulis Sims. Acta Farm. Bonaerense, 21, 5-8.

Dhawan, K.; Kumar, S. and Sharma, A. (2001), Antianxiety studies on extracts of Passiflora incarnata Linneaus. J. Ethnopharmacol., 78, 165-170.

Handley, S. L. and Mithani, S. (1984), Effects of alpha-adrenoceptors agonists and antagonists in a maze-exploration of fear-motivated behaviour. Naunyn. Schmiedebergs Arch. Pharmacol., 324, 1-5.

Lister, R. G. (1987), The use of a plus-maze to measure anxiety in the mouse. Psychopharmacol., 92, 180185.

Medina, J. H.; Paladini, A. C.; Wolfman, C.; Levi de Stein, M.; Calvo. D.; Diaz, L. E. and Pena, C. (1990), Chrysin (5,7-di-OH-flavone), a naturally-occurring ligand for benzodiazepine receptors, with anticonvulsant properties. Biochemical Pharmacol. 40, 2227-2230.

Newall, C. A.; Anderson, L. A. and Phillipson, J. D. (1996), Herbal medicines. A guide for health-care professionals. The Pharmaceutical Press, London, 206-207.

Okuyama, E.; Okamoto, Y.; Yamazaki, M. and Satake, M. (1996), Pharmacologically active components of a Peruvian medicinal plant, huanarpo (Jatropha cilliata). Chem Pharmac Bull, 44, 333-336.

Pellow, S. and File, S. E. (1986), Anxiolytic and anxiogenic drug effects on exploratory activity in an elevated plus-maze: a novel test of anxiety in the rat. Pharmacol. Biochem. Behav., 24, 525-529.

Rocha, F. F.; Lapa, A. J. and Lima, T. C. (2001), Evaluation of the anxiolytic-like effects of Cecropia glazioui Sneth in mice. Pharmacol. Biochem. Behav., 71, 183-190. 
Rolland, A.; Fleurentin, J.; Lanhers, M. C.; Younos, C.; Misslin, R.; Mortier, F. and Pelt, J. M. (1991), Behavioural effects of the American traditional plant Eschscholzia californica: sedative and anxiolytic properties. Planta Med., 57, 212-216.

Royce, J. R. (1977), On the construct vality of openfield measures, Psychological Bull., 84, 1098-1106.

Snyder, L. R.; Kirkland, J. J. and Glajch, J. L. (1997), Practical LC Methods Development. 2. ed. New York: John Wiley and Sons. 655 pp.

Soulimani, R.; Younos, C.; Jarmouni, S.; Bousta, D.; Misslin, R. and Mortier, F. (1997), Behavioural effects of Passiflora incarnata L. and its indole alkaloid and flavonoid derivatives and maltol in the mouse. J. Ethnopharmacol., 57, 11-20.

Speroni, E. and Minghetti, A. (1988), Neuropharmacological activity of extracts from Passiflora incarnata. Planta Med., 54, 488-491.

Wolfman, C.; Viola, H.; Paladini. A.; Dajas, F. and Medina, J. F. (1994), Possible anxiolytic effects of chrysin, a central benzodiazepine receptor ligand isolated from Passiflora coerulea. Pharmacol. Biochem. Behav., 47, 1-4.

Zanoli, P. R.; Avallone, R. and Baraldi, M. (2000), Behavioral characterisation of the flavonoids apigenin and chrysin. Fitoterapia, 71, S117-S123. 